\section{Ecology of Anopheline (Diptera, Culicidae), malaria vectors around the Serra da Mesa Reservoir, State of Goiás, Brazil. 1 - Frequency and climatic factors}

\author{
Ecologia de Anophelinae (Diptera, Culicidae), \\ vetores de malária em áreas da Usina Hidrelétrica \\ de Serra da Mesa, Estado de Goiás, Brasil. \\ 1 - Freqüência e fatores climáticos
}

Anthony Érico Guimarães 1

Carla Gentile 1

Jeronimo Alencar 1

Catarina Macedo Lopes 1

Rubens Pinto de Mello 1

\footnotetext{
1 Laboratório de Diptera,

Departamento

de Entomologia,

Instituto Oswaldo Cruz,

Fundação Oswaldo Cruz,

Rio de Janeiro, Brasil.
}

Correspondence Anthony Érico Guimarães Laboratório de Diptera,

Departamento de Entomologia, Instituto Oswaldo Cruz, Fundação Oswaldo Cruz. Av. Brasil 4365,

Rio de Janeiro, $R J$ 21045-900, Brasil. anthony@ioc.fiocruz.br

\begin{abstract}
The ecology of anopheline species (Diptera, Culicidae) was studied in the vicinity of the Serra da Mesa Reservoir, State of Goiás, Brazil. Climatic factors and frequency of anopheline populations were analyzed. Bimonthly humanbait and Shannon trap captures were conducted for 36 consecutive months (January 1997 through December 1999). A total of 5,205 adult anophelines belonging to five species were collected. Anopheles darlingi was the most frequently collected anopheline (61.4\%), followed by An. albitarsis s.l. (35.4\%), An. triannulatus. (2.5\%), An. oswaldoi (0.4\%), and An. evansae $(0.2 \%)$. The water level and vegetation along the banks of the reservoir were crucial to the frequency of the various anopheline species. Climatic factors had a secondary influence. The reservoir's water-level stability, increased frequency of An. darlingi, and the arrival of gold prospectors were responsible for the increase in malaria cases.
\end{abstract}

Malaria; Vectors Ecology;Ecology

\section{Introduction}

Human intrusion in natural ecosystems and the resulting environmental changes modify established niches and create conditions for new ecological configurations. Such changes provide opportunities for the establishment of mosquito vector populations and transmission of the respective vector-borne diseases.

A prime example of radical human intervention in the environment is the construction of hydroelectric power plants, with major ecological impacts on vector population dynamics. The risk of epidemics has been shown to increase as the result of deforestation, construction of hydroelectric dams, and the introduction of human population groups where insect vector-borne diseases are endemic.

In the present study, we observed the process of human intrusion $\rightarrow$ environmental change $\rightarrow$ anopheline population changes $\rightarrow$ and epidemics, over time. To better understand the ecology of mosquito populations, we evaluated changes in their population dynamics as a result of the imposed environmental impact. Systematic surveillance was conducted in five towns under the direct influence of the Serra da Mesa Reservoir in the State of Goiás by monitoring anopheline populations from the initial dam closure and reservoir flooding until the establishment of the plant's full activities (January 1997 to December 1999). 


\section{Material and methods}

The Serra da Mesa Reservoir is located in the Upper Tocantins River Basin, northern Goiás State (13o 50' S, 48o 18' W). The dam, 1,500 m long, $154 \mathrm{~m}$ high, and $460 \mathrm{~m}$ above sea level, is located on the main channel of the Tocantins River (Municipality of Minaçu) $1,790 \mathrm{~km}$ from its mouth (Figure 1). The Serra da Mesa Reservoir is the largest in Brazil in terms of water volume flow. During maximum flow the reservoir contains 54.4 billion $\mathrm{m}^{3}$, measures 1,784 $\mathrm{km}^{2}$, and extends to the limits of five main towns: Barro Alto, Campinorte, Minaçu, Niquelândia, and Uruaçu.

The reservoir is located in the cerrado (savannah) ecosystem, which in all occupies some two million km² of Brazil's territory. The Brazilian cerrado is occupied by an extensive plateau, between 300 and $600 \mathrm{~m}$ high, extending into the States of Amazonas, Rondônia, Pará, Maranhão, Piauí, Tocantins, Goiás, Mato Grosso, Mato Grosso do Sul, Bahia, Minas Gerais, and São Paulo and the Federal District.

This region features abundant metamorphic rock from the lower Proterozoic period and major natural deposits of asbestos in the municipality of Minaçu and nickel in the municipalities of Niquelândia and Barro Alto. Small granite outcroppings in the shape of residual peaks are occasionally observed. The Serra da Mesa Dam was built on the Goiano plateau consisting of a dome called the "Granito Serra da Mesa" and circled by deformed metamorphic rocks (e.g., paragneiss, quartzite, and micaschist)

The region's vegetation, influenced by the Serra da Mesa Reservoir, consists of sparse and relatively short trees that rarely reach a height of $10 \mathrm{~m}$, numerous bushes, and a lower layer of grassy plants. The trees often have large and rough leaves, with twisted thick-barked trunks and branches. These features are associated with high levels of aluminum in the soil rather than the lack of water. The twisting of trunks and branches is related to the frequent forest fires that result in the loss of the main shoots, stimulating the sprouting of surrounding buds, thus forming irregular and twisted branches. Even in the driest period these woody plants guarantee access to water through their long roots that can reach $20 \mathrm{~m}$ below the surface.

Gallery forests extend non-continuously along the river banks and in wet terrains, forming irregular patches of forest. The study area's climate is hot and tropical sub-humid. Average annual rainfall ranges from 1,500 to $2,000 \mathrm{~mm}$, with more than $70 \%$ of precipitation occurring from October through April (Figure 2). In the period of heavy rainfall the relative humidity frequently exceeds $90 \%$ and temperature highs are often above $40^{\circ} \mathrm{C}$. May through September is an extended intensely dry period with relative humidity levels often below $15 \%$ and infrequent light rains (e.g., $20 \mathrm{~mm}$ per month in 4 or 5 days of rain and dry periods that may last for as long as 50 consecutive days). The dry period is also the coolest, but temperatures rarely drop below $10 \circ \mathrm{C}$. Temperatures above $25^{\circ} \mathrm{C}$ are not uncommon, with the mean monthly temperatures during this period above $18 \circ \mathrm{C}$. This climatic profile is characteristic in regions that are distant from the coast and subject to strong continental effects.

Mosquito surveillance was conducted at five sites (Figure 1) in the area surrounding the Serra da Mesa Reservoir for three consecutive years, from January 1997 to December 1999. Each site has unique environmental characteristics.

- Site 1: Municipality of Minaçu: the sampling point is located in the construction area of the Serra da Mesa Dam, between 13o 49' 26.9" S and 48o 18' 56.5" W, next to the eastern bank of the Tocantins River, near the secondary reservoir ("Reservoir II") and 5km north of the primary reservoir (Figure 1). This area is characterized by dense woods or cerradão (literally "big savannah"), with 6 meter-high trees, the crowns of which limit the penetration of light to the lower undergrowth layers, resulting in a thick layer of organic matter. The gallery forests reach the edges of the reservoir, forming shadowy creeks in the many tributaries.

- Site 2: Municipality of Campinorte: the sampling point is located at $14005^{\prime} 38.5^{\prime \prime} \mathrm{S}$ and 480 59 ' 51.3" W, by the western bank of the Tocantins River, in a farming property known as Planeta Água, $18 \mathrm{~km}$ from the secondary access road to the town of Jerusalém, next to the BR153 highway (Figure 1). Collections were conducted along the banks of a creek that drains into the reservoir. The site is characterized by fertile soil and typical gallery forest vegetation, forming dense, mainly arboreal woods, with bushes in the lower undergrowth. Humidity and water from the drainage system sustain plant growth throughout the year, providing a habitat that does not suffer the intense climatic adversities of the dry period.

- Site 3: Municipality of Uruaçu: the sampling point is located at 140 32' $04.4^{\prime \prime} \mathrm{S}$ and 49o 01' 07.8" W, on the eastern bank and under the bridge over the Tocantins River, $7 \mathrm{~km}$ from the access crossroads to Uruaçu, from the GO-237 highway (Figure 1). There is an intense human migratory flux in this region, and there are many 
recreational activities associated with the reservoir. The wooded areas consist mostly of shrubs with few trees taller than $3 \mathrm{~m}$. The lower layer consists of small bushes and leaf-covered soil. The vegetation does not extend to the edges of the reservoir, where there are clear signs of deforestation. In the dry season, the few shadowy creeks are exposed to the sun and the banks become arid.

- Site 4: Municipality of Barro Alto: the sampling point is located at 140 39' 47.9" S and 48o 57 ' 35.2" $\mathrm{W}$, on the western bank of the Tocantins river and in mining areas and is $27 \mathrm{~km}$ from the secondary access road in the district of Placa, via the BR-080 highway (Figure 1). This area has been heavily altered by extensive mining activity. Human settlements are concentrated in crowded shacks. There is heavy traffic from transportation of people and mining equipment and materials, resulting in erosion of the road and surrounding area. The vegetation is characterized as cerradão, dominated by shrubs with occasional trees. The soil lacks organic matter, with frequent sandy patches exposed to intense sunlight. The sluggish waters of the Maranhão River form areas of sparse vegetation along the shady banks.

- Site 5: Municipality of Niquelândia: the sampling point is located at 140 26' $51.0^{\prime \prime} \mathrm{S}$ and 48 57' 34.6" W, on the eastern bank, in areas of the Córrego Dantas Farm, 9km from the secondary access road beginning at the Parada da Vendinha village, via the GO-237 highway (Figure 1). This region is characteristic of the Brazilian cerradão. Located between towns, the area consists of extensive plantations and cattle farms and small settlements where the local residents live off basic subsistence activities. The local population mostly lives in simple houses near the Reservoir, with everyday activities related to fishing. The environment has been extensively modified by deforestation and farming and livestock activities. Near the Reservoir there are dense stretches of shrubs with soil covered by grassy plants.

Mosquito captures were conducted bimonthly, always beginning at sunset (18:00h to 21:00h). Previous studies and random sampling around the reservoir showed that sunset and early evening hours were the most favorable periods for presence of anophelines. From October to February, during daylight savings time, captures were conducted between 19:00 and 22:00h.

Mosquitoes were simultaneously collected using human bait and Shannon light traps, with 100-candle gas lamps. Two members of the research team collected anophelines that
Figure 1

Location of the Serra da Mesa Hydroelectric Dam in Brazil and the State of Goiás, featuring anopheline collection sites $1,2,3,4$, and 5 .

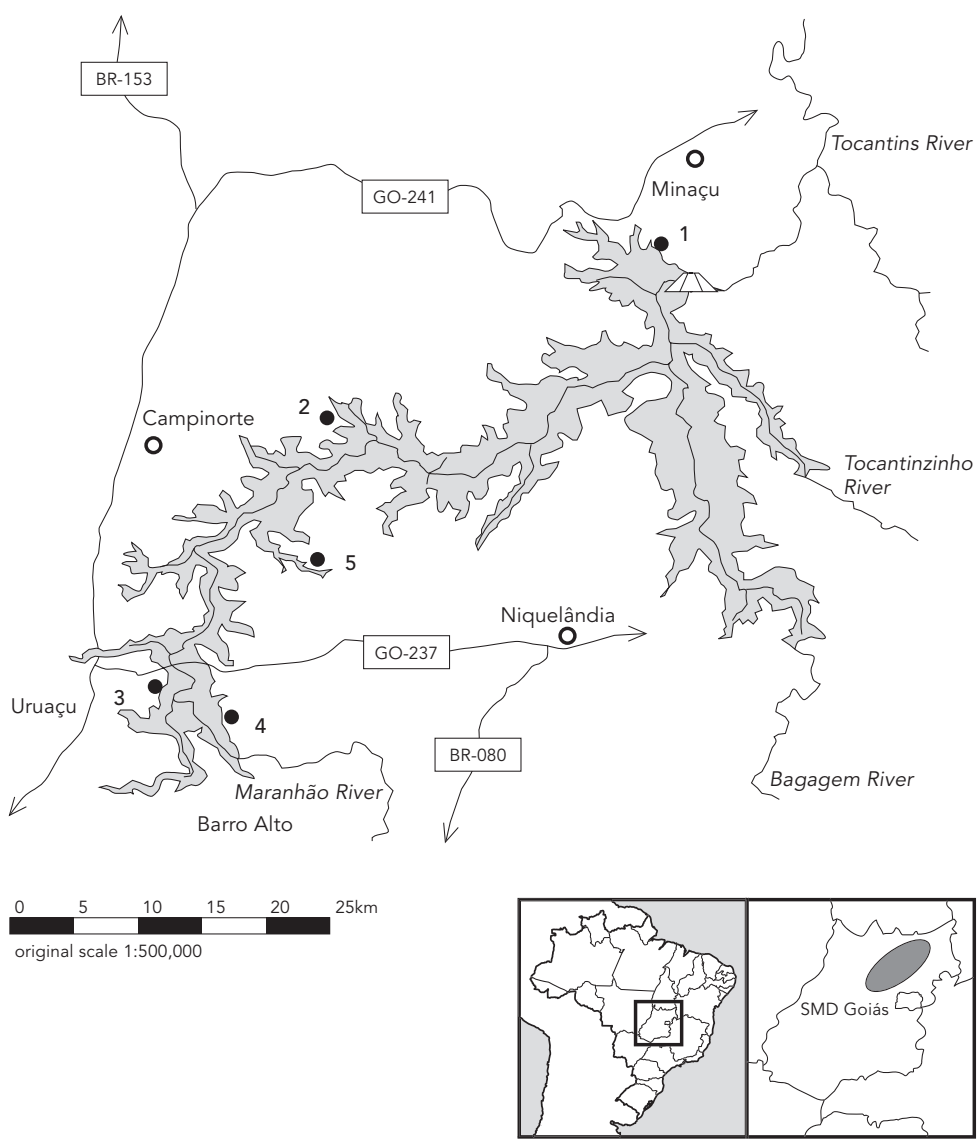

landed on the Shannon traps or on themselves with a mouth aspirator. The Shannon trap was located 150m from the human-bait captures.

Captured anophelines were killed with chloroform and placed in small boxes containing paraformaldehyde. The specimens were transported to the laboratory and mounted on paper triangles and labeled with a number and reference data.

All specimens were added to the collection of the Entomology Department of the Oswaldo Cruz Institute, Fiocruz, under the name "Serra da Mesa Collection”. Anopheles albitarsis specimens were considered sensu lato.

The relationship between the flooding stage of the reservoir and presence of anophelines was determined by the Williams mean test $\left(\mathrm{X}_{\mathrm{w}}\right)$. The level of significance between the fre- 
Temperature, relative humidity, and rainfall measurements and monthly averages, verified during sampling around the Serra da Mesa Reservoir, State of Goiás, Brazil, from January 1997 to December 1999.

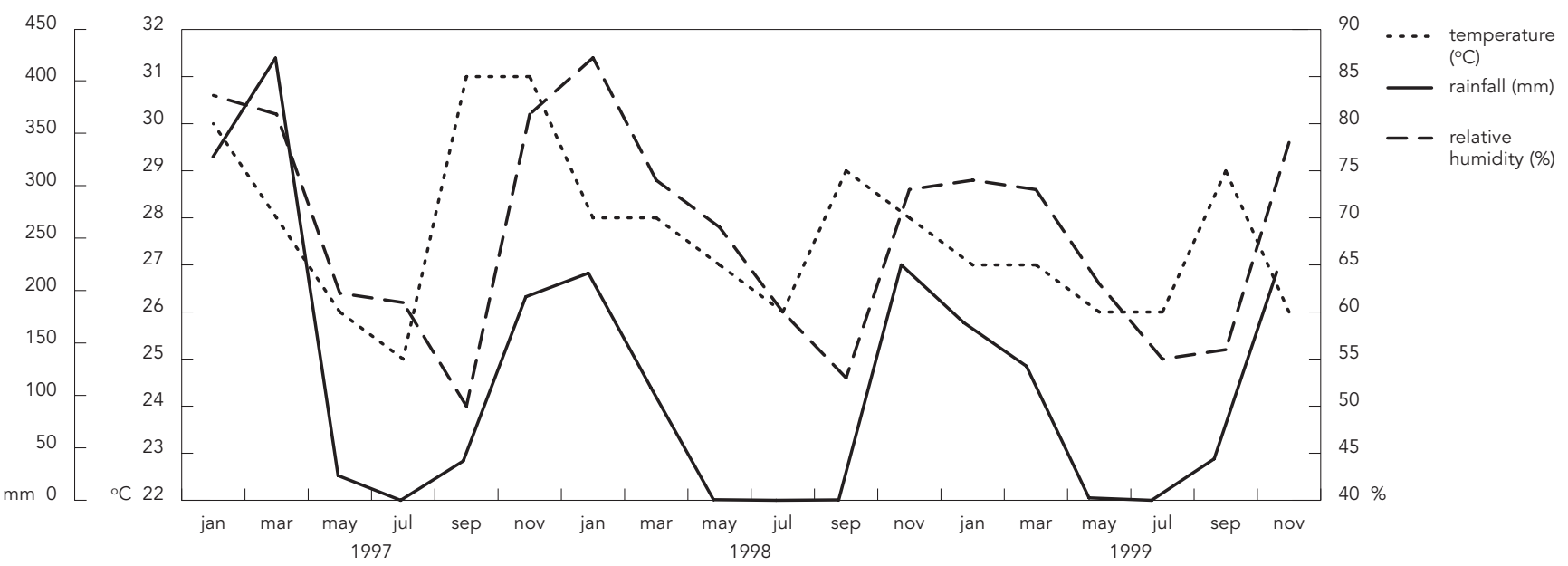

quency of anophelines and diagnosed malaria cases was established using the linear correlation coefficient. Data on malaria cases around the reservoir were obtained from the Goiás office of the Brazilian National Health Foundation (FUNASA).

\section{Results}

From January 1997 to November 1999, 5,205 anophelines were collected at the five study areas. Five species were collected: Anopheles darlingi, An.albitarsis, An.triannulatus, An.oswaldoi, and An.evansae (Table 1).

Throughout the three-year study period, An.darling $i$ was the most frequently captured species, comprising $>50 \%$ of the specimens captured at each sampling site. Overall, $A n$. darlingi represented $61.4 \%$ of all anophelines captured. Calculation of the mean frequency confirmed the abundance of this anopheline throughout the area. An.albitarsis was the second most common species in all the sampling sites, with $35.4 \%$ of all the anophelines collected. An.triannulatus, An.oswaldoi, and An. evansae were captured much less frequently.

Environmental variations during the study resulted in variations in the anopheline fauna during filling of the reservoir. From 1997 to 1999 there was a drop in anopheline frequency from $\mathrm{X}_{\mathrm{w}}=169.1$ in 1997 to $\mathrm{X}_{\mathrm{w}}=115.2$ in 1998 (a decrease of 32\%) and $X_{\mathrm{w}}=20.8$ in 1999 (a decrease of $82 \%$ ), or a total reduction of $88 \%$ in the anopheline population (Figure 3 ).

The gradual reduction was common to all five species over time, that is, An. darlingi was always the most common, followed by An.albitarsis, An.triannulatus, An.oswaldoi, and An. evansae (Figure 3). The proportions of the two most frequently captured species, An.darlingi and An.albitarsis, remained more or less constant. In 1997 they represented 56\% and 39\% of all the anophelines, respectively, with an average frequency of $\mathrm{X}_{\mathrm{w}}=95.4$ and $\mathrm{X}_{\mathrm{w}}=66.4$. They represented $60 \%$ and $38 \%$ of all the anophelines in 1998 and $64 \%$ and $30 \%$ in 1999 .

The frequency curve of the anophelines showed two peaks during the filling of the reservoir. The first peak occurred from July 1997 to March 1998, with means varying from $X_{\mathrm{w}}=64.0$ to $\mathrm{X}_{\mathrm{W}}=155.0$. The second occurred in March $1999\left(\mathrm{X}_{\mathrm{w}}=61.4\right)$ (Figure 3).

This pattern was observed for four of the species. The only exception was An. evansae, which was not captured during the second peak. Small annual variations occurred in the first larger population peak for the less commonly collected species: An.triannulatus, An. oswaldoi, and An.evansae (Figure 3).

Variations in anopheline frequency are believed to be directly related to interventions in the environment around the Serra da Mesa Reservoir. Among the most important events 
Number $(n)$, percentage $(\%)$, and Williams means $\left(X_{w}\right)$ of anophelines captured by sampling site, Serra da Mesa Reservoir, State of Goiás, Brazil, January 1997 to December 1999.

\begin{tabular}{|c|c|c|c|c|c|c|c|c|c|c|c|c|c|c|c|c|c|c|}
\hline \multirow[t]{2}{*}{ Species } & \multicolumn{3}{|c|}{ Site 1} & \multicolumn{3}{|c|}{ Site 2} & \multicolumn{3}{|c|}{ Site 3} & \multicolumn{3}{|c|}{ Site 4} & \multicolumn{3}{|c|}{ Site 5} & \multicolumn{3}{|c|}{ Total } \\
\hline & $\mathrm{n}$ & $\%$ & $X w$ & $\mathrm{n}$ & $\%$ & $X w$ & $\mathrm{n}$ & $\%$ & $X_{w}$ & $\mathrm{n}$ & $\%$ & $X w$ & $n$ & $\%$ & $X w$ & $\mathrm{n}$ & $\%$ & $X_{w}$ \\
\hline Anopheles darlingi & 658 & 64.2 & 6.6 & 88 & 73.9 & 1.8 & 847 & 64.8 & 11.7 & 551 & 72.5 & 10.4 & 1,053 & 52.8 & 15.4 & 3,197 & 61.4 & 46.9 \\
\hline An. albitarsis s.l. & 356 & 34.7 & 4.3 & 19 & 16.0 & 0.6 & 435 & 33.3 & 6.6 & 191 & 25.1 & 3.6 & 844 & 42.3 & 14.9 & 1,845 & 35.4 & 28.0 \\
\hline An. triannulatus & 9 & 0.9 & 0.3 & 10 & 8.4 & 0.4 & 23 & 1.8 & 0.6 & 9 & 1.2 & 0.3 & 78 & 3.9 & 2.0 & 129 & 2.5 & 2.6 \\
\hline An. oswaldoi & 2 & 0.2 & 0.1 & 2 & 1.7 & 0.1 & 3 & 0.2 & 0.1 & 5 & 0.7 & 0.2 & 11 & 0.6 & 0.4 & 23 & 0.4 & 0.6 \\
\hline An. evansae & 0 & 0.0 & 0.0 & 0 & 0.0 & 0.0 & 0 & 0.0 & 0.0 & 4 & 0.5 & 0.1 & 7 & 0.4 & 0.2 & 11 & 0.2 & 0.3 \\
\hline Total & 1,025 & 100.0 & 9.5 & 119 & 100.0 & 2.1 & 1,308 & 100.0 & 17.1 & 760 & 100.0 & 13.9 & 1,993 & 100.0 & 28.8 & 5,205 & 100.0 & 74.6 \\
\hline
\end{tabular}

were the closing of the bypass tunnels and filling of the reservoir.

In October 1996 the bypass tunnels were closed, and in January 1997 the reservoir began to form. The reservoir was filled continuously until 1997. From the closing of the bypass tunnels until the end of the rainy season, the water level increased from $340 \mathrm{~m}$ to $431 \mathrm{~m}$ above sea level.

Variation in precipitation between the months of maximum and minimum rainfall was consistent with the region's climatic profile. However, the dry season was extremely long, and even with the beginning of rains in November 1997, there was no significant increase in the reservoir's water level. Rainfall was approximately half that observed in the previous year. Temperature and relative humidity remained at the expected levels (Figure 2).

Until March 1998, rainfall was less than expected, and the region suffered another extremely dry period from May to September 1998. Resumption of the rainy season, from October 1998 to May 1999, once again fell short of the expected level. Average temperature and relative humidity did not reach the levels of previous years.

\section{Discussion}

Obtaining entomological information by monitoring populations of disease vectors has proven to be a vital measure of disease risk assessment. Therefore, detailed studies of vector population bionomics are relevant for developing and implementing control programs.

It has been shown that environmental changes may alter the frequency of malaria $1,2,3,4,5,6$ Such changes are particularly relevant in regions altered by human intrusion, including dam construction, mining, and rural settle- ment projects that provide increased opportunities for anthropophilic vector populations and where the environment favors the latter, thereby increasing the epidemiological risks. $7,8,9,10,11,12$

Intense and extensive deforestation, partial obstruction of rivers and creeks, highway earthwork without proper drainage, accumulation of water, and the formation of large manmade lakes are examples of environmental changes that can result in increased vector density, favoring vector-borne endemics.

In the current study we observed anopheline population changes over time in areas under the influence of the Serra da Mesa Reservoir, from the beginning of the filling of the reservoir until months after the initial hydroelectric plant operation. The five sites were selected to provide a representative sample of the region. Monitoring populations over time was essential to assess environmental effects.

An.darlingi is endophilic and anthropophilic and is captured using human bait both inside and outside residences. It is also the primary human malaria vector species in much of Brazil, and even transmits malaria when the species' density is low. $2,5,13,14$

The second most frequent species in our survey, An. albitarsis sensu lato, also plays an important role in malaria epidemiology in Brazil. That is, although it is normally present as a secondary vector, it may acquire greater significance where transmission by An.darlingi already occurs.13,15,16 This species is an efficient colonizer of areas altered by human activity, and the increase in its population deserves attention due to its vector efficiency. 12,17,18,19,20 Wilkerson et al.21 distinguished four genetically differentiated species from An. albitarsis sensu lato using random amplified polymorphic DNA polymerase chain reaction 
296

Guimarães AE et al.

Figure 3

Incidence of anopheline species and malaria cases according to calculation of Williams means $\left(X_{w}\right)$ around the Serra da Mesa Reservoir, State of Goiás, Brazil, from January 1997 to December 1999.
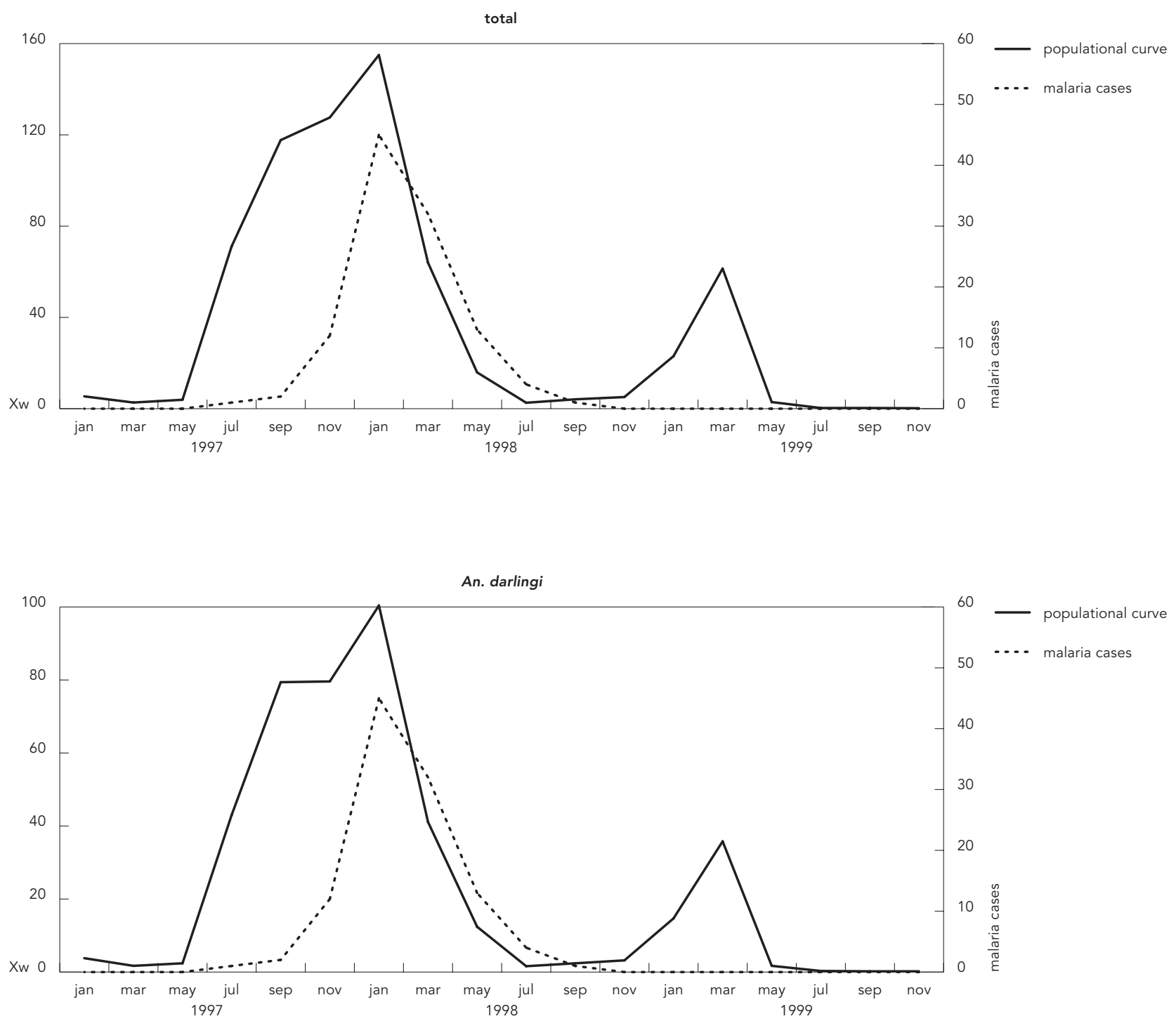

(continues)

Cad. Saúde Pública, Rio de Janeiro, 20(1):291-302, jan-fev, 2004 
ECOLOGY OF ANOPHELINE VECTORS

297

Figure 3 (continued)

Incidence of anopheline species and malaria cases according to calculation of Williams means $\left(\mathrm{X}_{\mathrm{w}}\right)$ around the Serra da Mesa Reservoir, State of Goiás, Brazil, from January 1997 to December 1999.
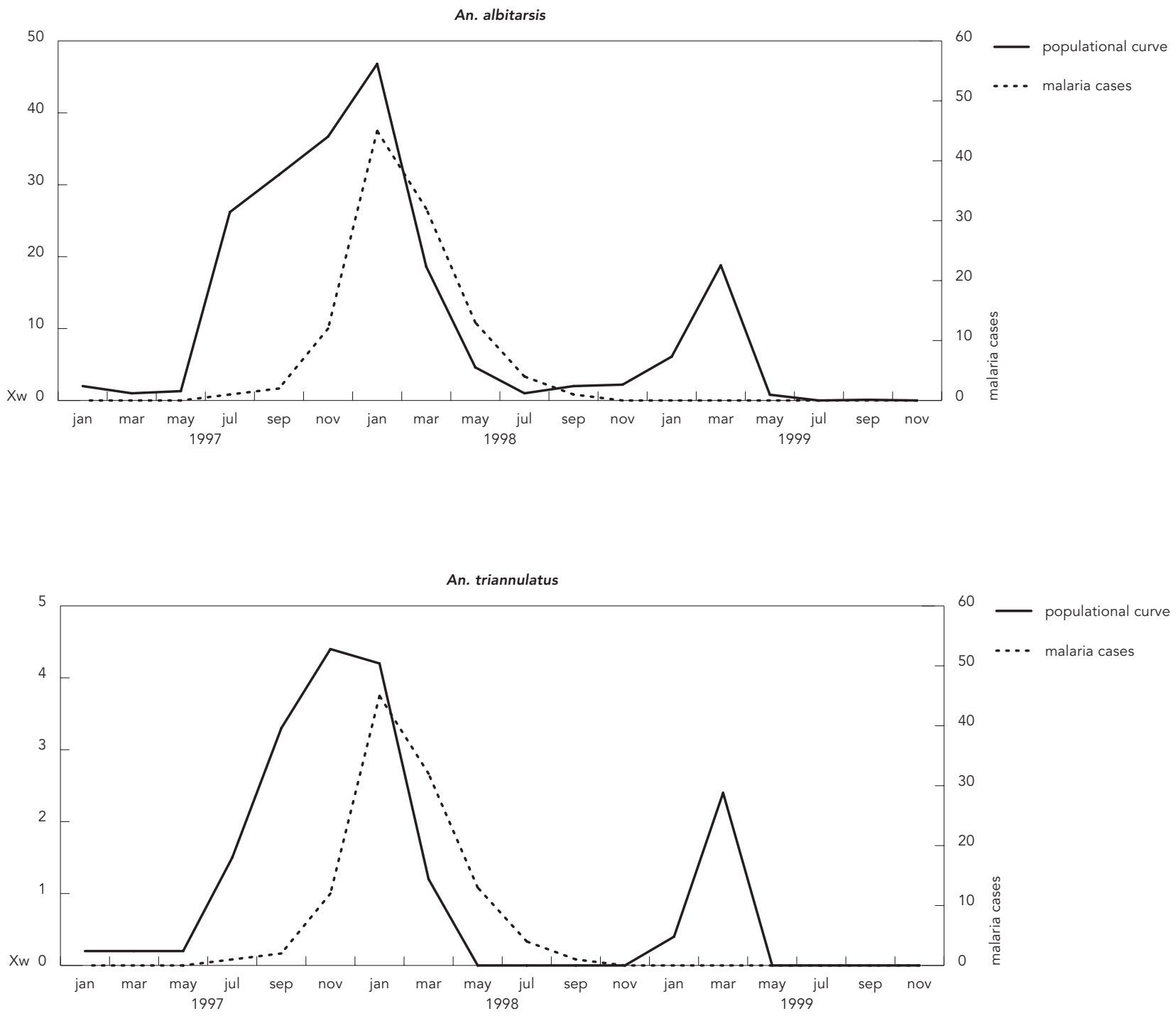

(continues)

Cad. Saúde Pública, Rio de Janeiro, 20(1):291-302, jan-fev, 2004 
Figure 3 (continued)

Incidence of anopheline species and malaria cases according to calculation of Williams means $\left(X_{w}\right)$ around the Serra da Mesa Reservoir, State of Goiás, Brazil, from January 1997 to December 1999.
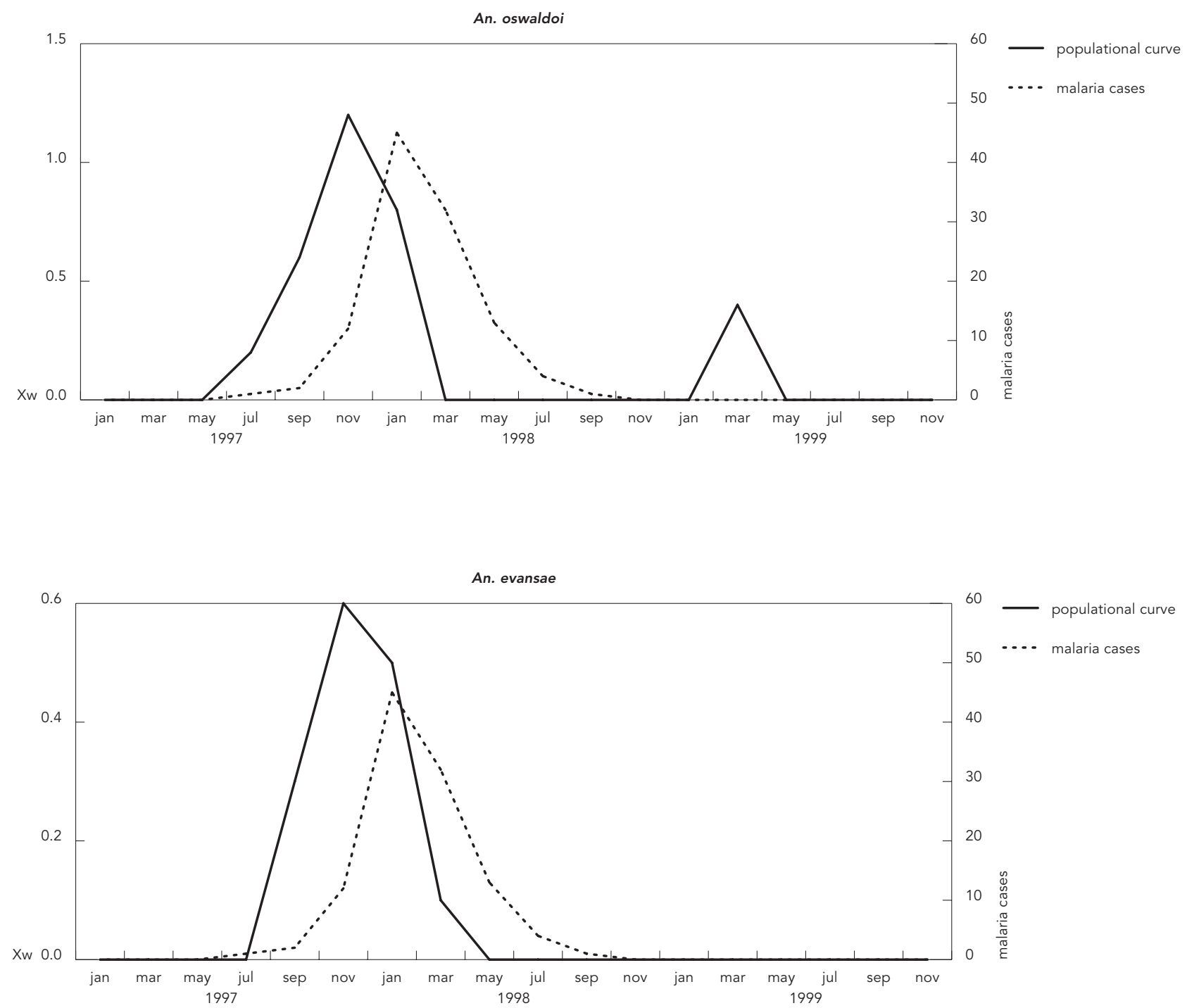
(RAPD-PCR). Wilkerson et al. 22 hypothesized the species as An. albitarsis sensu stricto, An. marajoara, An.deaneorum, and another species not described. An.marajoara and An.deaneorum were responsible for a malaria outbreak in Costa Marques, Rondônia State, as was An.marajoara in Iguape, São Paulo State, and Marajó Island, Pará State.22 Conn et al.23 observed a significant proportion of An. marajoara infected with malaria parasites using ELISA and incriminated the species as a primary vector in sites near the city of Macapá, Amapá State. Other authors have implicated species from the An. albitarsis complex as the principal malaria vector in certain locations, such as the Vale do Ribeira region in the State of São Paulo 20, around the Itaipu Hydroelectric Dam in the state of Paraná 6 , and in urban areas of Boa Vista in the State of Roraima 24. Although they consider An. albitarsis s.l. zoophilic 25, Lourenço-de-Oliveira et al. 2, Forattini et al. 20, and Guimarães et al. 6 report the species' intense anthropophilic behavior, biting humans inside and outside residences, especially in the absence of large animals (like cattle) in the surrounding area.

An. triannulatus, An. oswaldoi, and An. evansae were captured much less frequently and are typically zoophilic and exophilic. An. triannulatus and An. oswaldoi have been implicated in the transmission of human malaria 26. However, Klein 27,28 demonstrated that $A n$. triannulatus in Costa Marques, Rondonia State, was a highly inefficient vector for both $P$. falciparum and P. vivax. Specimens of An.oswaldoi were even reported to infrequently have sporozoites in the salivary glands, although they presented oocysts. Since naturally infected specimens have been found, some authors incriminated the species as a secondary vector in certain locations 17,18,25,29. The low numbers of An.evansae captured and lack of reports concerning its vector activity make this species' involvement in malaria transmission rare.

Anopheline population dynamics are directly related to the availability of larval habitats for immature development. Some authors observed an association with increased rainfall that provides greater opportunity for accumulation of small bodies of water 8,30,31,32. However, Guimarães et al. 6 noted that in areas under the influence of the reservoir, anopheline population dynamics are not directly influenced by rainfall, but by the level of the reservoir which, while stable, offers a constant opportunity for female anophelines to lay their eggs.

In this study we observed the relationship between variation in anopheline populations and the water level of the reservoir. Climatic factors had a secondary influence, generating variations in the conditions around the reservoir and along the banks of tributaries. This process involved three different stages.

Despite optimum temperature conditions, relative humidity, and heavy rainfall from January to April 1997 (Figure 2), deforestation up to 10 meters above the expected level along the banks of the reservoir and tributaries was a key factor for the absence of anophelines (Figure 3 ). Erosion, muddy water, and direct exposure of breeding sites to sunlight were unfavorable to anopheline species in the area, especially An.darlingi (Figure 4).

With the gradual filling of the reservoir and reforestation along the banks beginning in May 1997, a second stage began, with less fluctuation in the water levels and an immediate increase in anophelines captured.

The third stage, beginning in July 1998, was characterized by a continuous drop in the water level (Figure 4) and a reduction in the occurrence of anophelines. Initially, this could be explained by the beginning of the operation stage of the Serra da Mesa Hydroelectric Plant during the dry season. However, in July 1998 what would become one of the longest droughts in history in the area hit nearly the entire country for the next three years. From the beginning, hydroelectric plants in various other areas of the country were threatened by the lack of water in their reservoirs, and the Serra da Mesa Plant was forced to work at higher capacity to compensate for the national power deficit. The rainy period that followed was shorter than expected, failed to produce more water than was released, and lasted until the end of our study.

The impact of the increased reservoir level on the anopheline population was not the same as observed during the drop in the water level. From the moment the water level reached the surrounding vegetation at a slowly increasing pace, conditions favored the development of immature anopheline forms. On the other hand, when the water receded the banks were soon exposed to sunlight and erosion and became less suitable for the development of immature forms (Figure 4). The consequences of these conditions for the anopheline population were immediate, and the data show a large decrease in adult specimens captured, concomitant with reduced water levels in the reservoir in July 1998 (Figure 3).

In November 1998 there was an increase in rainfall, temperature, and relative humidity, typical of summer in the study area (Figure 2). 


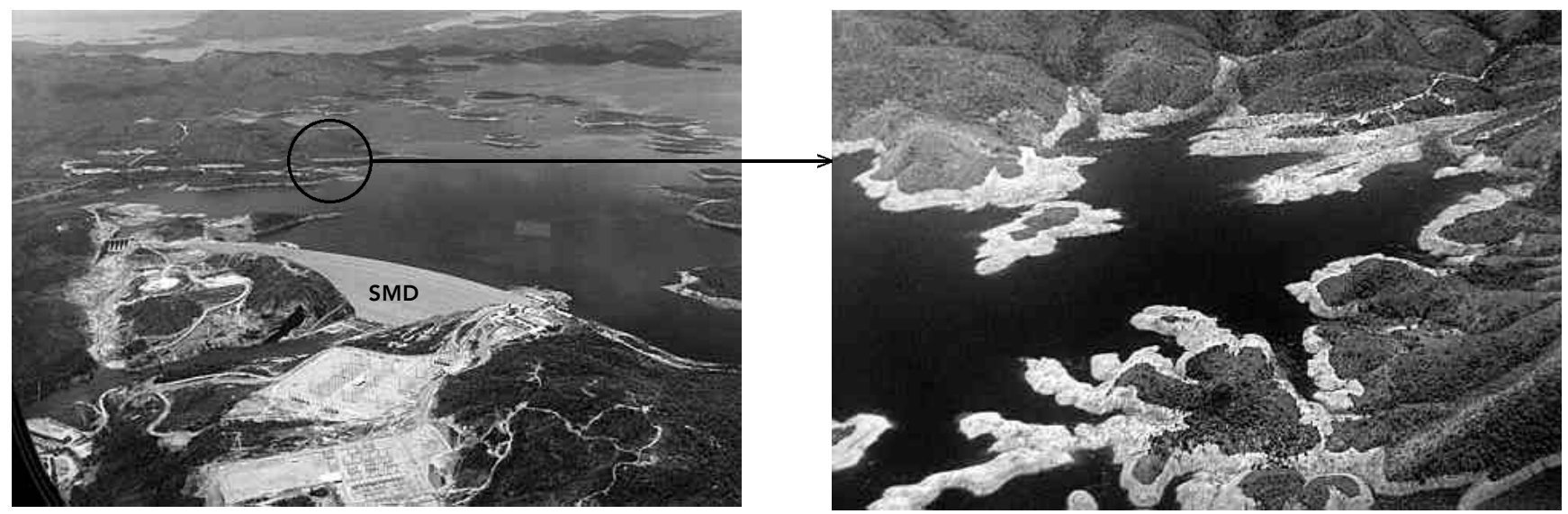

Although the numbers did not reach the normal values for the same period in previous years, they were sufficient to reduce the speed at which the water level decreased. Besides stabilizing the reservoir for several months, the rains resulted in increased vegetation, a typical cerrado behavior, and increased the potentially suitable larval habitats with a concurrent increase in the number of anophelines captured up to May 1999 (Figure 3). In May 1999 the drought continued, resulting in decreased reservoir levels. Few anophelines were captured during this period.

According to Forattini et al. 8 and Guimarães et al. 32 , the alternation between Culicidae population peaks and sudden decreases are opportunistic reactions to favorable environmental situations; when the latter end, the anopheline populations return to their normal level. This phenomenon was observed partially in the area around the Serra da Mesa Reservoir.

The present study focused primarily on entomological factors and ecological aspects affecting anopheline populations in an environment altered by human activity. However, in the epidemiology of malaria, the effects of human ecology are essential, and the flow of humans in the Brazilian countryside has always been identified as a modulating factor in the distribution and frequency of the disease 7,9,25,33.
Construction of highways, hydroelectric plants, and farming and mining operations, including the best planned ones, always generate a disorganized migration of people that makes sanitation and disease control very difficult. According to Guimarães et al. 6, construction of the Itaipu Hydroelectric Dam in the State of Parana resulted in an increase in anopheline populations and the return of migrant workers who had failed to settle in the Northern region, many of whom were infected with malaria, resulting in a serious epidemic, with nearly 3,000 cases of malaria in areas where the disease had already been eliminated some 30 years before.

Human migration and malaria are common in mining areas under the impact of the reservoir, concentrating many risk factors for transmission of the disease. These areas lack adequate infrastructure, and contact between humans and the vector is favored by precarious housing, proximity to larval habitats, and intense exposure, since miners tend to be insufficiently clothed while working during hours when the vector is highly active. There is always a multiplicity of breeding sites in these regions due to the way in which the area is modified. Besides the workers directly involved in mining operations themselves, mining areas attract individuals involved in prostitution and unofficial trade, with high mobility and social 
detachment that hinder epidemiologic control measures. Many of these individuals are already infected with malaria when they arrive, having originated from or passed through regions where the disease is endemic 1,3,6,9,14,33.

The arrival of gold prospectors and all the risk components mentioned above became evident in the area around the Serra da Mesa Reservoir beginning in July 1997. As discussed, during this same period we observed an in-

\section{Resumo}

Foram estudados aspectos da ecologia de anofelinos (Diptera, Culicidae) em áreas da Usina Hidrelétrica de Serra da Mesa, Estado de Goiás, Brasil. Foram analisados a incidência das populações de anofelinos e os fatores climáticos. Foram realizadas capturas bimestrais, em isca humana e armadilha Shannon, ao longo de 36 meses consecutivos (janeiro de 1997 a dezembro de 1999). Capturamos um total de 5.205 anofelinos adultos,pertencentes a cinco espécies. Anopheles darlingi foi o anofelino mais freqüente $(61,4 \%)$, seguido de An. albitarsis s.l. (35,4\%), An. triannulatus (2,5\%), An. oswaldoi $(0,4 \%) e$ An. evansae $(0,2 \%)$. O nível da água e a vegetação às margens do reservatório foram determinantes para a freqüência das espécies de anofelinos. Os fatores climáticos tiveram influência secundária. A estabilidade do reservatório, o aumento na freqüência do An. darlingi e a chegada de garimpeiros foram responsáveis pelos casos de malária diagnosticados.

Malária; Ecololgia de Vetores;Ecologia

\section{Contributors}

A. E. Guimarães collaborated in the field work, species identification, statistical analysis, and drafting of the article C. Gentile participated in the field work and statistical analysis. J. Alencar and C. M. Lopes participated in the field activities and species identification. R. P. Melo participated in the field work.

\section{Acknowledgements}

This work was accomplished with the help of Furnas Centrais Elétricas S.A. The authors wish to thank the Environmental Department of Furnas Centrais Elétricas S.A., represented by Dr. Norma Pinto Vilela, for providing logistic support during the fieldwork. We also thank our colleagues Ariovaldo Gomes Coelho, Chisto Soares da Silva, and Dion Kenede Vieira for their collaboration in the field activities. crease in the anopheline population, especially An.darlingi, in all the sites studied. There appears to be a direct relationship between this migratory flow, the advent of diagnosed malaria cases, and the increased frequency of $A n$. darlingi (and perhaps also of An. albitarsis) (Figure 3). The important relationship between these factors is indicated by the linear correlation indices obtained: An.darlingi $=0.606$ and An.albitarsis $=0.601\left(\mathrm{r}_{0,1(2), 9}=0.521\right)$.

\section{References}

1. Tadei WP, Santos JMM, Costa WLS, Scarpassa VM. Biologia de anofelinos amazônicos. XII. Ocorrência de espécies de Anopheles, dinâmica da transmissão e controle da malária na zona urbana de Ariquemes (Rondônia). Rev Inst Med Trop São Paulo 1988; 30:221-51.

2. Lourenço-de-Oliveira R, Guimarães AE, Arlé M, Silva TF, Castro MG, Motta MA, et al. Anopheline species, some of their habits and relation to malaria in endemic areas of Rondônia State, Amazon Region of Brazil. Mem Inst Oswaldo Cruz 1989; 84:501-14.

3. Tadei WP, Santos JMM, Scarpassa VM, Rodrigues IB. Incidência, distribuição e aspectos ecológicos de espécies de Anopheles (Díptera: Culicidae) em regiões naturais e sob impacto ambiental da Amazônia Brasileira. In: Ferreira EJG, Santos GM, Leão ELM, Oliveira LA, organizadores. Bases Científicas para Estratégias de Preservação e Desenvolvimento da Amazônia. Manaus: Instituto Nacional de Pesquisas da Amazônia; vol. 2. 1993. p. 167-96.

4. Marques AC, Cardenas H. Combate a malária no Brasil: evolução, situação atual e perspectivas. Rev Soc Bras Med Trop 1994; 27:91-108.

5. Quintero LO, Thatcher BD, Tadei P. Biologia de anofelinos amazônicos. XXI. ocorrência de espécies de Anopheles e outros culicídeos na área de influência da Hidrelétrica de Balbina - cinco anos após o enchimento do reservatório. Acta Amazônica 1996; 26:281-96.

6. Guimarães AE, Mello RP, Lopes CM, Alencar J, Gentile C. Prevalência de anofelinos (Diptera: Culicidae) no crepúsculo vespertino em áreas da Usina Hidrelétrica de Itaipu, no Município de Guairá, Estado do Paraná, Brasil. Mem Inst Oswaldo Cruz 1997; 92:745-54.

7. Bruce-Chwatt LJ. Leland Ossian Howard (18571950) and malaria control: them and now. Mosquito News 1981; 41:215-25.

8. Forattini OP, Gomes AC, Natal L, Santos JLF. Observações sobre atividade de mosquitos Culicidae em mata primitiva da planície e perfis epidemiológicos de vários ambientes no Vale do Ribeira, São Paulo, Brasil. Rev Saúde Pública 1986; 20:178-203. 
9. Bulcão JAS. Proposta de um modelo para avaliação do impacto dos empreendimentos hidrelétricos sobre as doenças transmitidas por vetores, com especial referência à malária [Tese de Doutorado]. Rio de Janeiro: Instituto Oswaldo Cruz, Fundação Oswaldo Cruz; 1994.

10. Tadei WP. O gênero Mansonia (Díptera, Culicidae) e a proliferação de mosquitos na Usina Hidrelétrica de Tucuruí. In: Magalhães SB, Brito RC, Castro ER, organizadores. Energia na Amazônia. v. 2. Belém: Universidade Federal do Pará/Associação de Universidades Amazônicas; 1996. p. 311-8.

11. Forattini OP. Mosquito culicidae como vetores emergentes de infecções. Rev Saúde Pública 1998; 32:497-502.

12. Natal D, Barata EAMF, Urbinatti PR, Barata JMS, Paula MB. Sobre a fauna de mosquitos adultos (Diptera: Culicidae) em áreas de implantação de hidrelétrica na bacia do Rio Paraná, Brasil. Revista Brasileira de Entomologia 1998; 41:213-16.

13. Deane LM. Malaria vectors in Brazil. Mem Inst Oswaldo Cruz 1986; 81:5-14.

14. Tadei WP, Thatcher BD; Santos JMM, Scarpassa VM, Rodrigues IB, Rafael MS. Ecologic observations on anopheline vectors of malaria in the Brazilian Amazon. Am J Trop Med Hyg 1998; 59:325-35.

15. Teodoro U, Guilherme ALF, Lozovei AL, Salvia Filho V, Fukushigue Y, Spinosa RP, et al. Culicídeos do lago de Itaipu no rio Paraná, sul do Brasil. Rev Saúde Pública 1995; 29:6-14.

16. Tadei WP, Thatcher BD. Malaria vectors in the Brazilian Amazon: Anopheles of the subgenus Nyssorhynchus. Rev Inst Med Trop São Paulo 2000; 42:87-94.

17. Arruda M, Carvalho MB, Nussenzweig RS, Maracic M, Ferreira AW, Cochrane AH. Potential vectors of malaria and their different susceptibility to Plasmodium falciparum and Plasmodium vivax in Northern Brazil identified by immunoassay. Am J Trop Med Hyg 1986; 35:873-81.

18. Oliveira-Ferreira J, Lourenço-de-Oliveira R, Teva A, Deane LM, Daniel-Ribeiro CT. Natural malaria infections in anophelines in Rondônia state, Brazilian Amazon. Am J Trop Med Hyg 1990; 43: 6-10.

19. Rubio-Palis Y. Vectorial capacity of anophelines in western Venezuela (Capacidad vectorial de los anofelinos del occidente de Venezuela). J Am Mosq Control Assoc 1992; 8:307.

20. Forattini OP, Kakitani I, Massad M. Studies on mosquitoes (Diptera: Culicidae) and anthropic environment. 7 - Behaviour of adult Nyssorhynchus anophelines with special reference to Anopheles albitarsis s. $l$. in South-Eastern Brazil. Rev Saúde Pública 1995; 29:20-6.

21. Wilkerson RC, Gaffigan TV, Lima JB. Identification of Species Related to Anopheles (Nyssorhynchus) albitarsis by Randon Amplified Polymorphic DNAPolymerase Chain Reaction (Diptera: Culicidae). Mem Inst Oswaldo Cruz 1995; 90:721-32.
22. Wilkerson RC, Parsons TJ, Klein TA, Gaffigan TV, Bergo E, Consolim J. Diagnosis by Random Amplified Polymorphic DNA Polymerase Chain Reaction of Four Cryptic Species Related to Anopheles (Nyssorhynchus) albitarsis (Diptera: Culicidae) from Paraguay, Argentina and Brazil. J Med Entomol 1995; 32:697-704.

23. Conn JE, Wilkerson RC, Segura MNO, Souza RTL, Schlichting CD, Wirtz RA, et al. Emergence of a new neotropical malaria vector facilitated by human migration and changes in land use. Am J Trop Med Hyg 2002; 66:18-22.

24. Silva-Vasconcelos A, Kato MYN, Mourão EM, Souza RTL, Lacerda RNL, Sibajev A, et al. Biting Indices, Host-seeking Activity and Natural Infection Rates of Anopheline Species in Boa Vista, Roraima, Brazil from 1996 to 1998. Mem Inst Oswaldo Cruz 2002; 97:151-61.

25. Deane LM. Malaria studies and control in Brazil. Am J Trop Med Hyg 1988; 38:223-30.

26. Dixon K, Roberts DR, Llewellyn CH. Contribuição ao estudo epidemiológico da malária em trechos da Rodovia Transamazônica, Brasil. Rev Inst Med Trop São Paulo 1979; 21:287-92.

27. Klein TA, Lima JBP, Tada MS. Comparative Susceptibility of Anopheline Mosquitoes to Plasmodium falciparum in Rondonia, Brazil. Am J Trop Med Hyg 1991; 44:598-603.

28. Klein TA, Lima JBP, Tada MS, Miller R. Comparative Susceptibility of Anopheline Mosquitoes in Rondonia, Brazil, to Infection in by Plasmodium vivax. Am J Trop Med Hyg 1991; 45:463-70.

29. Rosa-Freitas MG, Lourenço-de-Oliveira R, Carvalho-Pinto CJ, Flores-Mendonza C, Silva-doNascimento TF. Anopheline species complexes in Brazil. Current knowledge of those related to malaria transmission. Mem Inst Oswaldo Cruz 1998; 93:651-5.

30. Hayes J, Charlwood JD. Dinâmica estacional de uma população de Anopheles darlingi numa área endêmica de malária no Amazonas. Acta Amazonica 1979; 9:79-86.

31. Forattini OP. Comportamento exófilo de Anopheles darlingi Root, em região meridional do Brasil. Rev Saúde Pública 1987; 21:291-304.

32. Guimarães AE, Mello RP, Lopes CM, Gentile C. Ecology of mosquitoes (Diptera: Culicidae) in areas of Serra do Mar State Park, State of São Paulo, Brazil. I - Monthly frequency and climatic factors. Mem Inst Oswaldo Cruz 2000; 95:1-16.

33. Tauil PL. Comments on the epidemiology and control of malaria in Brazil. Mem Inst Oswaldo Cruz 1986; 81:39-41.

Submitted on $11 /$ Mar/2003

Final version resubmitted on 13/Jun/2003

Approved on 21/Oct/2003 